NBER WORKING PAPER SERIES

\title{
BOY-GIRL DIFFERENCES IN PARENTAL TIME INVESTMENTS: EVIDENCE FROM THREE COUNTRIES
}

\author{
Michael Baker \\ Kevin Milligan \\ Working Paper 18893 \\ http://www.nber.org/papers/w18893 \\ NATIONAL BUREAU OF ECONOMIC RESEARCH \\ 1050 Massachusetts Avenue \\ Cambridge, MA 02138 \\ March 2013
}

We thank workshop participants at Aarhus University, the Institute for Fiscal Studies, Michigan State, National Taiwan University, Notre Dame, University of Waterloo, the Canadian Economics Association Annual Meetings and NBER Summer Institute for helpful comments on earlier drafts of this research. We gratefully acknowledge the research support of SSHRC (Baker Grant, \#410-2008-0346, 410-2011-0724). Kirsten Cornelson, Kevin Fawcett and Peter Wang provided excellent research assistance. We also gratefully acknowledge the assistance and support of Dan Feenberg and the NBER, facilitating and hosting our access to the ECLS-B data. We thank the staffs of the Toronto and B.C. Research Data Centres for their technical support. This paper represents the views of the authors and does not necessarily reflect the views of Statistics Canada or the National Bureau of Economic Research.

At least one co-author has disclosed a financial relationship of potential relevance for this research. Further information is available online at http://www.nber.org/papers/w18893.ack

NBER working papers are circulated for discussion and comment purposes. They have not been peerreviewed or been subject to the review by the NBER Board of Directors that accompanies official NBER publications.

(C) 2013 by Michael Baker and Kevin Milligan. All rights reserved. Short sections of text, not to exceed two paragraphs, may be quoted without explicit permission provided that full credit, including $\mathbb{C}$ notice, is given to the source. 
Boy-Girl Differences in Parental Time Investments: Evidence from Three Countries

Michael Baker and Kevin Milligan

NBER Working Paper No. 18893

March 2013, Revised September 2013

JEL No. J13,J16,J22,J24

\begin{abstract}
$\underline{\text { ABSTRACT }}$
We study differences in the time parents spend with girls and boys at preschool ages in Canada, the U.K. and the U.S. We refine previous evidence that fathers commit more time to boys, showing this greater commitment emerges with age and is not present for very young children. We next examine differences in specific parental teaching activities such as reading and the use of number and letters. We find the parents commit more of this time to girls, starting at ages as young as 9 months. We explore possible explanations of this greater commitment to girls including explicit parental preference and boy-girl differences in costs of these time inputs. Finally, we offer evidence that these differences in time inputs are potentially important: in each country the boy-girl difference in inputs can account for a non-trivial proportion of the boy-girl difference in preschool reading and math scores.
\end{abstract}

Michael Baker

Department of Economics

University of Toronto

150 St. George Street

Toronto, ON M5S 3G7

CANADA

and NBER

baker@chass.utoronto.ca

Kevin Milligan

Department of Economics

University of British Columbia

\#997-1873 East Mall

Vancouver, BC V6T 1Z1

CANADA

and NBER

kevin.milligan@ubc.ca 


\subsection{Introduction}

The apparent failure of boys to thrive in primary, secondary, and post-secondary education has captured the public interest, leading to concerns about a "boys crisis." What lies behind sex differences in schooling achievement? Advances in brain science provide insight to the differential development of girls' and boys' cognitive abilities that may play a role (e.g., Halpern 2011). Some argue that social and economic norms have turned against males (Rosin 2012). In this paper we investigate whether parents in Canada, the United States and the United Kingdom invest their time differently in young girls and boys. Parents' time is an important input to children's human capital development, and recent research tells us parents' time investments vary by the characteristics of parents and children. ${ }^{1}$ Any difference in parents' time investments by their child's sex may contribute to the well-documented boy-girl gaps in outcomes at older ages.

Evidence of human capital differences by sex emerges at young ages. In table 1, we present estimates of sex differences in test scores and cognitive measures at the preschool level. We report the means of vocabulary and math test scores at ages 4 and 5 for girls and boys born in the 2000s in Canada, the U.S. and the U.K. We also report a 'conditional difference,' estimated by ordinary least squares controlling for some standard observable characteristics (described below) and inferring the difference from an indicator variable for a male child. In almost all cases boys trail girls at the mean, with the gap ranging from $12 \%$ to $18 \%$ of a standard deviation. The emergence of this gender achievement gap at school entry is particularly salient given widespread agreement on the importance of early childhood experiences and investments to later life outcomes (e.g., Almond and Currie 2011).

\footnotetext{
${ }^{1}$ Guryan et al. (2008), Ramey and Ramey (2010) and Sayer et al. (2004) study how parents' characteristics are associated with parental investments. Zick and Bryant (1996) and Price (2008) study how these investments vary by child characteristics. 
Most previous research on how parents' investments differ between girls and boys is for developing countries. The suspected source of any boy-girl differences is an explicit parental preference for male offspring. Studies have documented a male advantage in nutrition (e.g., Das Gupta 1987), healthcare (e.g., Ganadtra and Hirve 1994) and vaccination rates (e.g., Borooah 2004). Jayachandran and Kuziemko (2011) and Barcellos et al. (2012) are two recent contributions to this literature finding boy-girl differences in breastfeeding duration, childcare, vaccination rates, and vitamin supplementation.

There is much less evidence of boy-girl differences in developmental inputs for developed countries (see Lundberg 2005a, and Raley and Bianchi 2006, for recent reviews of the literature). Males do seem to receive more total time from their parents due to extra input from their fathers (Lundberg 2005b and Lundberg et al. 2007). Disaggregating total time into several categories, Yeung et al. (2001) report boys receive relatively more of their fathers' time for play and companionship activities. ${ }^{2}$

We begin our analysis in this paper refining this evidence for developed countries. We focus on differences in parents' time investments in their daughters and sons at the ages (0-4) leading up to these pre-school tests reported in table 1. Exploiting larger data sets that are now available we show that any boy advantage in parents' aggregate time inputs is not evident at very young ages. Instead, it first emerges at ages 3 through 5.

One limitation of evidence on parents' aggregate time inputs is the lack of a clear connection to children's cognitive development. We next extend the literature by examining parental time spent teaching their children skills such as new letters and words, numbers and reading. These teaching activities have a clearer relationship with the cognitive skills that are

\footnotetext{
${ }^{2}$ Bryant and Zick (1996) provide evidence of the types of activities mothers and fathers participate in with their children is related to the child's gender.
} 
evaluated by educational testing, and are the specific targets of public campaigns to increase the time parents spend with their children. In Canada, the U.K. and the U.S., starting as early as 9 months of age, we find parents spend more teaching time with girls than with boys. Parents spend more time with girls reading, telling stories, singing songs, drawing, and teaching new words and letters.

We next try to distinguish among three leading explanations of why parents might treat girls and boys differently. One explanation is that girls and boys are intrinsically different—-they have different production functions that turn parental investments into child outcomes. A second explanation is parents may prefer to invest differently in girls and boys, because parents care more, or differently, about the outcomes of one sex. A final explanation is that the costs of investing in girls and boys may differ.

Our most compelling evidence comes from our evaluation of the preference explanation. We show that, like their higher time commitments to sons, fathers' stated preference for sons only emerges as the child ages. At the young ages at which we document the boy-girl difference in parents' teaching activities, neither mothers nor fathers exhibit a strong stated preference for boys or girls. We also examine boy-girl differences in parents' teaching time with fraternal twins. Parents may prefer to treat these twins with greater equality than they would singleton girls and boys. However, we document boy-girl differences in parents' teaching time between these twins that are comparable to the effects documented in the full sample of children. Finally, we present evidence that there are no strong boy-girl differences in parents' stated expectations for children at young ages. The sum of this evidence speaks against a simple preference based explanation of the different amounts of teaching time girls and boys receive. 
While direct tests of intrinsic differences in boys' and girls' production functions have been conducted in other fields, we have no leverage in our data sets to pursue them here. Instead we present evidence that conditional on any boy-girl differences in production functions the magnitude of the boy-girl difference in teaching time varies with variables that arguably shift the cost of providing this time to children. In each of our countries we find that the sex difference in teaching time is larger in families with two unmarried adults than in families with single or married parents. ${ }^{3}$ We also find in the majority of the countries that the boy-girl difference in teaching time is larger for more highly educated mothers, and if the mother does not work.

In the final step in the analysis we provide an indication of how much these boy-girl differences in teaching activities might matter. We examine how controlling for the sex differences in teaching time changes the estimated boy-girl gaps in test scores at ages 4 and 5 we have reported in table 1. In each country, we find the change is non-trivial. Controlling for the differences in teaching time attenuates the boy-girl gaps in test scores by roughly $23-25$ percent in the U.S., 16-23 percent in the U.K., and more than one-third in Canada. Given evidence that reading time with parents has a causal effect on children's test scores (Price 2012, Kalb and van Ours 2013), these results suggest the boy-girl difference in parents' teaching time that we document could contribute to the differences in human capital girls and boys exhibit at school entry.

\subsection{Why would parents treat girls and boys differently?}

The three leading explanations of why parents might treat girls and boys differently are differences in production functions, preferences, or the costs of investing. A strict trichotomy,

\footnotetext{
3 This evidence potentially ties in with Bertrand and Pan's (2013) finding that at older ages single parent households are a particularly difficult environment for boys. 
however, is potentially misleading because the explanations may overlap. This renders the task of distinguishing cleanly among them challenging. In this section we discuss these three prongs of the argument and how they may interact.

One source of different production functions for girls and boys might be intrinsic cognitive differences. ${ }^{4}$ For example, differences at early ages favoring girls have been found in attention, fine motor skills, speaking and reading, while boys tend to have the advantage in cognitive perception and visuospatial skills. At early ages (e.g., 16-30 months) evidence suggests girls lead boys by about a month of development and at preschool ages exhibit greater comprehension and use more complex verbal construction. These differences could be biological. For example, one theory is that males' higher prenatal exposure to androgens leads to right hemisphere brain dominance, which brings males advantage in cognitive tasks associated with this hemisphere. ${ }^{5}$ An alternative explanation is psychosocial. The values and stereotypes of society — at early ages the different ways parents and caregivers dress, interact with and teach girls and boys—-have formative effects on children's cognitive abilities. For example, Fryer and Levitt (2010) find that the gender gap in mathematics scores varies across countries and is correlated with gender-segregated schooling.

If girls and boys have different production functions (that map parents' inputs into outcomes), parents might rationally invest in girls and boys differently. For example, those seeking equal outcomes for their children might tailor their investments to compensate for any systematic skill deficits between girls and boys. Price (2012) presents evidence of such compensating investments in reading time, although not in the boy-girl context. Alternatively,

\footnotetext{
${ }^{4}$ Much of the following discussion follows Halpern (2011).

${ }^{5}$ Interestingly, Halpern (2011) concludes that documented physical differences in male and female brains-for example in grey and white matter and structures such as the hypothalamus-have so far been shown to have little leverage to account for sex differences in cognition.
} 
parents' investments may reinforce existing skill differences (e.g., Becker and Tomes 1976, Aizer and Cunha 2012)_for example, they may spend more time in speaking and reading activities with girls. Parental preference for boys, documented in fertility outcomes, is the leading explanation of boy-girl differences in parental investment in developing countries. In contrast, there is a general consensus that, on average, parents in developed countries instead have a preference for a child of each sex (e.g., Angrist and Evans 1998 for the U.S. and McDougall et al. 1999 for Canada). Within some immigrant/ethnic communities, though, there is evidence of son preference in the United States and Canada (Abrevaya 2009 and Almond et al. 2013). Also, Dahl and Moretti (2008) argue the son preference in the U.S is more widespread. Another way that parental preference for children of a specific sex has been documented is through direct solicitation. For the U.S., Dahl and Moretti (2008) cite Gallop polls showing fathers have a significant preference for sons. Kohler et al. (2005) report that self-reported happiness of fathers in Denmark after a first-born son is higher than after a first-born daughter. For mothers there is no relationship between the gender of the first born and happiness.

The third explanation for boy-girl differences in parental investments is the different costs of raising girls and boys. The different costs may include both the monetary outlay on material inputs and the opportunity costs of parental time. For example, one unit of time input may be more costly for the parent to deliver to a boy than to a girl or vice versa.

While our description of these explanations might suggest neat delineations of the sources of differential parental investment, this is unlikely to be true. For example, one might try to define explanations that are external to the child (e.g., parental preferences, input costs, societal norms) and explanations that are internal to the child (e.g., production functions). However, epigenetics tells us that children biologically evolve in part in response to their 
environment. Likewise, Pollack and Wachter (1975) note that the price of parental time may reflect parental preferences as well as market opportunity costs. This means that the preference and input cost explanations do not necessarily identify separate mechanisms, respectively, internal and external to the parents. We remain mindful of these challenges in the interpretation of our results.

\subsection{Data and Empirical Framework}

Our main data sets are representative samples of children born in Canada, the U.S. and the U.K in the 2000s. The use of three countries allows us to exploit complementary questions and survey coverage across countries, as well as check that results for the U.S. hold up in other similar developed countries. For Canada the data come from the National Longitudinal Survey of Children and Youth (NLSCY). The NLSCY is a nationally representative survey of Canadian children conducted biennially between $1994 / 95$ and 2008/09. We use waves 4-8, focusing on children of the birth years 1999 through 2004. Due to the biennial structure of the survey, these children are surveyed at ages $0 / 1,2 / 3$ and 4/5. For the U.S., our main data are the Early Childhood Longitudinal Survey-Birth Cohort (ECLS-B). This survey is nationally representative of children born in 2001. We use data from the first three rounds, which survey the children when they were approximately 9 months old, 2 years old and 4 years old. For the U.K. our data are the Millennium Cohort Study (MCS) that samples children born in 2000/01. We use data from the first three "sweeps" which were collected when the children were roughly 9 months, 3 years and 5 years of age.

Each of these surveys reports cognitive test results, as documented earlier in table 1, when the child is about to enter the formal school system. As discussed below, each survey also 
contains an array of variables that record the intensity of parents' activities with their children, such as reading, singing and using new words and numbers.

A number of other data sets are also used in the analysis. The first is the American Time Use Survey (ATUS), a nationally representative survey of the American population used extensively in past research on parents' commitments of time to their children. We use the 2003 through 2011 waves. The second is the National Survey of Family Growth (NSFG). This is a nationally representative survey of the American household population of men and women between the ages of 15 and 44 . We use the 2002 and 2006-08 waves. The third supplemental data source is the Maternity Experiences Survey (MES). The target population of this Canadian survey is biological mothers who were 15 years of age or older at the time of their singleton live birth, who were living with their infant, and whose child was born in late 2005 or 2006.

We follow the practice of previous studies (e.g. Dahl and Moretti 2008) by focusing the analysis on samples of first-born children. It is among first-born children that we can view a child's sex as most likely to be randomly assigned. However, if family dynamics mean that a mother's first born is not the oldest child in the household and if there are significant birth/ageorder effects in the treatment of children (e.g., Price 2008), then the way to define the sample is not straightforward. The details of how we identify the first born in each data set are reported in the appendix, and where possible we experiment with alternative definitions of the sample and report any sensitivity of the results.

Much of our analysis involves regressing some outcome of interest $y_{i}$ on a limited set of control variables $X_{i}$ and a dummy variable for males $M_{i}$.

(1) $y_{i}=X_{i} \beta+\varphi M_{i}+\varepsilon_{i}$, 
The vector $X i$ includes controls for child's age, mother's age, education and foreign birth, and regional and city location controls. The exact definitions of these variables for the various data sets are reported in the appendix. We do not control for the mother's marital status or the number of siblings because these may be outcomes of the child being male. ${ }^{6}$ In almost all cases, the controls have little effect on the inference. ${ }^{7}$

\subsection{Parental Time Commitments to their Children}

The starting point for our analysis is previous research on parents' time with their children. We refine this evidence of parents' overall time commitment by investigating its variation as children age, and in particular any differences in the time girls and boys receive when they are very young. We then change focus, examining parents' time spent in specific teaching activities, which are plausibly more directly linked to children's cognitive abilities.

\subsection{Aggregate time allocation by sex of child}

The analysis of parents' aggregate time investments in the U.S., using the ATUS data, is presented in table 2. With the additional waves of the ATUS now available we are able to focus on smaller age intervals than in previous research, and in particular parents' time inputs when their children are very young. In the first panel are the results for the sample of first-born children at age 2 and younger. We examine measures of the amount of time mothers and fathers are involved in the primary (meaning a child-focused activity) and secondary (meaning children

\footnotetext{
${ }^{6}$ There is evidence from the U.S. that male and female children grow up in different family structures. For example, Dahl and Moretti (2008) relate family structure to the sex of the first-born child. They report that among families with children aged 12 and younger, a first born female (versus male) raises the probability of an absent father by 3.1 percent, the probability that the mother has never married by 1.4 percent, the probability that parents are divorced by 1.3 percent and the probability that the mother has custody of the children in the event of a divorce by 2.9 percent. Related evidence is presented in Lundberg and Rose (2002). We have run regressions that include controls for marital status, father's characteristics, and siblings. Adding these controls has little impact on the estimates.

${ }^{7}$ This can be easily checked in our tables by comparing the difference in the reported male and female means to the 'conditional difference' that comes from our regression including controls.
} 
are present when another activity is undertaken) care of their children. We also examine time spent in some specific activities. These include physical care (which can be particularly important at young ages) and play and sports, which is the category that previous research indicates where we should see a higher commitment of fathers to sons. For each measure, we report the unconditional mean for first born girls and boys in the first two columns. The third column reports the coefficient $\varphi$ for the boy dummy from equation (1) and standard error.

For mothers' time, none of the boy-girl differences in table 2 is statistically significant. Also, most of the estimates are quite small and there is also no systematic pattern in their signsome are negative, some are positive. For fathers' time, the estimated differences are a bit bigger in magnitude, but again all are statistically insignificant. There is no strong evidence here of unequal treatment of girls and boys.

The results for the sample where the first born child is age 3-5 are in the second panel. Again the estimates for mothers are all statistically insignificant, and all are quite small. However, for fathers we start to see a higher commitment of time to boys. There are now statistically significant differences in time committed to secondary care and to play that favor boys. For the former the difference is 24 minutes per day, while for the latter it is just over 10 minutes per day. Together with the results in the first panel this evidence for older children indicates that any extra time boys receive from their fathers emerges as the child ages. Fathers' extra commitment to boys does not appear to be an intrinsic characteristic of the relationship throughout the early years.

We do not have time diary data for Canada, but the NLSCY does have data on how frequently parents perform certain daily activities with children when they are ages 4 and 5 . The person most knowledgeable (PMK) about the child is asked how often s/he eats, plays, talks 
through things, does chores or goes on outings with his/her child. The categories of response are: 1) every day, 2) 5-6 days per week, 3) 3-4 days per week, 4) 1-2 days per week, 5) 1-2 days per month and 6) rarely or never. We reverse the scale so a higher a number means more frequent activity to be consistent with other activity questions examined below. We also select only the cases where the PMK is the mother, because the PMK is also separately asked how often his/her spouse or partner does these activities with the child. This way we can separately examine mothers' and fathers' time input. The responses we examine cover all mothers, but the responses for fathers are for families where both mother and her partner are present.

The results are reported in table 3 . The estimates for mothers are mostly negative, indicating a higher frequency of the activities with girls, but all are statistically insignificant. In contrast the estimates for fathers are all positive, and the result for play is statistically significant. Consistent with the U.S. evidence, by the time the child is at the upper end of our age interval of interest fathers spend more time playing with their sons. ${ }^{8}$

\subsection{Mothers time at home following birth}

Maternal/parental care in the very first months of a child's life is thought to be critical to their subsequent development. This is one of the reasons governments in most developed countries have legislated maternity leave mandates that provide mothers job protected, and often compensated, leave from employment post birth. We next investigate whether there are systematic differences in the period of time mothers remain home post birth with their first born daughters and sons. While maternity leave mandates differ across Canada, the U.K. and the U.S., we focus here on any sex based differences in mothers' time at home post birth conditional on these differences.

\footnotetext{
${ }^{8}$ We have also examined data from the United Kingdom Time Use Diary. Unfortunately, sample sizes for our target group in this survey are very small and so these data are not informative In samples for the oldest child the number of mothers averages about 200 in the two age groups, while the number of fathers is just over 60.
} 
The U.S. results are presented in the first panel of table 4. In the first rows we report the months of maternal care the child received in the indicated period. ${ }^{9}$ The measures are based on survey variables capturing the age at which the child first entered non-parental care. For both periods there is little evidence the sex of the child is related to amount of maternal care received in the first years. This inference is supported in the next two rows where we examine whether the mother has returned to work since the baby was born. Here our measures are based on variables asking whether the mother has yet returned to work, and how old the child was when she returned, recorded in the first wave.

In the second panel are the results for Canada. Here again there is little evidence that the incidence of return to work is related to the sex of the child. However, among those who returned, the mothers of boys returned just over 2 weeks earlier. Note how much lower the incidence of return to work is in Canada than the U.S., presumably due to the more generous provision of maternity leave in that country.

In the last panel are the results for children in the U.K.. We report results for whether the mother has returned to work conditional on previously working, the unconditional rate of working at the time of the survey, and the proportion of mothers reporting they currently take care of the home and of children. For each of these variables there is no evidence of a difference related to the sex of the child.

Overall, we find little evidence that either boys or girls receive more days of maternal care post-birth. This is further evidence that, at very young ages, parents display little sex preference in their provision of general time inputs to their first born girls and boys.

\footnotetext{
${ }^{9}$ We choose the periods - 6 months and 16 months - based on the age of the youngest child in waves 1 and 2 , so the response is observable for all respondents.
} 


\subsection{Parents' Time Inputs Promoting Cognitive Abilities}

As noted, a limitation of the previous results is the use of aggregate time categories. The link between aggregate time spent with the child and the child's developmental outcomes is not necessarily direct. Fortunately, the ECLS-B, NLSCY and MCS data each contain questions that ask parents about activities with their children that have a more transparent relationship to cognitive development. These include teaching activities such as reading, singing, playing action games and teaching the use of letters and numbers. Price (2012) reports that variation in a similar question on the frequency of reading with a child in the U.S. National Longitudinal Survey of Youth has an effect on standardized reading tests scores. Kalb and van Ours (2013) find that reading at ages 4 and 5 has a positive effect on reading and cognitive skills up to ages 10 and 11 .

In each survey the questions ask the frequency of a given activity in a reference time period. For the U.S., the ECLS-B captures the frequency of the activity in the "typical week" on a 4 point scale: 1) not at all, 2) once or twice, 3) 3-6 times and 4) every day. For Canada, the NLSCY records answers on a five point scale: 1) rarely or never, 2) a few times a month, 3) once a week, 4) a few times a week and 5) daily, for the past month. Finally for the U.K., the coding in the MCS is for a typical week on a seven point scale ranging from "occasionally" to "7 times per week/constantly". For each activity there is a separate question about the incidence of the activity indicating whether the activity is done at all. We incorporate the response to this question as a new, lowest, level of intensity so the variable captures both incidence and intensity as in the other surveys. ${ }^{10}$

\footnotetext{
${ }^{10}$ In the MCS the targeted respondent to the questions differ somewhat by age. At age 3 the question is if "anyone at home" does the activity, except for the question about reading that solicits the activity of the main respondent and any partner separately. At age 5 the response is for the main respondent and the partner. Where needed, we again reverse the codes so a higher number implies greater frequency.
} 
The analysis of these variables is presented in tables 5,6 and 7. The U.S. and Canadian data provide a view of the activities when the child is very young (first panels of tables 5 and 6). In both countries the estimates for all the activities are negative, indicating lower levels of the activities for boys. In the U.S. the estimate for reading is statistically significant, while in Canada the estimates for reading, playing action games and teaching new words are statistically significant. Therefore at a very early age a pattern of parents engaging in teaching activities less frequently with boys is apparent.

In the lower panels of tables 5 and 6 , and in the U.K. results in table 7, we can see if this initial boy-girl difference persists at older ages. In all three countries it does. The estimates are again mostly negative and more uniformly statistically significant. Not only do parents read less with boys, but also tell stories, sing songs, visit the library, teach letters and numbers, paint and do musical activities. The one exception to this pattern is positive estimates for some physical activities like going on walks, to the park, and running errands.

Boy-girl differences in the incidence (rather than the intensive margin of frequency) of some activities are contributing to these results. For example in the U.S. at age 2 girls are more likely to have gone to the library in the past month by 6 percentage points. The questions on incidence for the U.K reveal that girls are a statistically significant 5.5 percentage points more likely to have someone at home help them learn the alphabet.

The ECLS-B also provides data on the provision of additional resources that may promote cognitive development. At age 2 (table 5) boys have a statistically significant fewer number of books and CDs/records. 


\subsection{Summary}

The evidence in this section of parents' time investment in their children both refines and extends the literature. Our focus on finer age groupings, and particularly parents' inputs when children are very young, reveals that the greater amount of time fathers spend with their sons emerges as the child ages. At very young ages both mothers and fathers provide time to the sons and daughters fairly equally. However, when we focus on the content of these time investments, and in particular the time spent in teaching activities, we find there is unequal provision of time in favor of girls. The implication of these differences, however, is not immediately clear. Certainly parental time is a central construct in the economic models of the production of children's human capital (e.g., Becker and Tomes 1986). However, there is not yet an empirical consensus on what kinds of time are critical, although this question is being actively pursued in many disciplines (e.g., Farah et al. 2008, Paxson and Schady 2007).

\subsection{Sources of Boy-Girl Differences in Parental Time Inputs}

Our investigation of the reasons parents commit more time to teaching activities with girls than with boys begins with the preference explanation. We offer direct evidence on parents' preferences for girls versus boys, examine boy-girl differences in teaching inputs for different sex fraternal twins and also study any sex differences in parents' expectations for their children. We then investigate whether, conditional on any gender difference in production functions, the magnitude of the boy-girl differential in teaching time varies by the characteristics of the mother. This analysis of characteristics aims to gather information on how boy-girl differences line up with the opportunity cost of providing inputs. 


\subsection{The Preference Explanation}

Previous evidence that parents prefer girls or boys is built on analyses of fertility outcomes and responses of family structure to male or female births, or direct solicitation of parents' preference. We begin our analysis of preferences by adopting a refinement of the latter approach because we are interested in parents' preferences when their child is very young, and how their opinions might change as the child ages.

Both the NSFG for the U.S. and the MES for Canada solicit mothers' opinions about the birth of their child. They ask whether the conception was timed properly (overdue, right time or mistimed) and whether it was wanted (indifferent, unwanted, not sure). The respondent is asked to answer the questions thinking back to the time just before she got pregnant. The answers are recorded, however, after the birth has taken place. Therefore, if the instructions are followed correctly there is no reason to expect a correlation of the answers with the sex of the offspring. To the extent there is a correlation, one way of interpreting the responses is as a direct solicitation of parental preferences for girls or boys, conditional on their child's current age. In both surveys are reports of both the mothers' responses to the questions as well as the fathers' response as reported by the mother.

The analysis of these data is presented in table 8 . In the first panel are the results from the NSFG for first born children aged 2 or younger. This age interval roughly matches the ages in our Canadian data and focuses on children born in the 2000s. Just over 50 percent of pregnancies are viewed as being at the right time while the proportion unwanted ranges from 6 to over 10 percent. The responses of mothers show a slight preference for girls, although it is only marginally statistically significant. For the fathers' responses (as reported by the mother) there is effectively no relationship with the gender of the child. In the second panel are the results from 
the Canadian MES for the sample of children aged 5-15 months. The proportion of pregnancies at the right time is marginally lower than in the U.S. and the proportion unwanted is substantially so. Also echoing the results from the first panel for the U.S. there is very little evidence of a relationship between the responses and the child's gender.

These estimates do not suggest that parents have strong preferences for male or female first-born children. Previous evidence (e.g. Dahl and Moretti 2008) suggests that fathers prefer boys. However, the evidence in the first two panels of table 8 is for when children are very young, while previous evidence is for broader age ranges. The NSFG allows us to investigate whether this is an important distinction by obtaining estimates for older first born children. The results in the third panel of table 8 are for the sample of first born children aged $3-5 .{ }^{11}$ These results are better aligned with previous evidence. Mothers' responses now exhibit a small preference for boys, although the estimates are small and mostly statistically insignificant. The big change is for the fathers' opinions, which swing significantly in favor of boys. Fathers' opinions of the wantedness of boys relative to girls appear to evolve through time.

This difference in the fathers' preferences by the child's age suggests that fathers' stated preference for males may not be intrinsic to the sex of the child at birth, but acquired as the child ages and the fathers experience the differences of parenting girls and boys. Interestingly the fathers' preference for boys emerges at the same ages that they start making a relatively larger time commitment to sons (as seen in tables 2 and 3). This interpretation of the data is supported by analysis of ECLS-B data, which asks similar questions about the pregnancy in the first wave when the child is 9 months old. In these data, the estimate of the male dummy variable for whether the mother viewed the pregnancy as wanted is $0.003(0.015)$, and for the mother's report

\footnotetext{
${ }^{11}$ Note because we use the 2002 and 2006-2008 waves, our sample includes children born as early as 1996 .
} 
of whether her partner's view is $0.003(0.015) .{ }^{12}$ There is again no evidence in these data of a parental preference for males when the child is very young.

We next take a different approach to the preference explanation, asking whether the boygirl difference in teaching time is appreciably changed in a situation where we expect parents to have an explicit preference to treat them the same-fraternal twins. Because fraternal twins are only as genetically similar as any other sibling pair, the key twin feature we wish to exploit is their common developmental environment, and in particular their parents' preference to treat them similarly. Whether parents treat fraternal twins similarly, relative to identical twins, is a topic of ongoing debate. The "equal environment assumption" is a foundation of twin studies that compare monozygotic and dizygotic pairs (e.g., Medland and Hatemi 2009). ${ }^{13}$ For our purposes here we want to exploit the fact that parents wish to treat opposite sex dizygotic twins with greater similarity than parents generally treat sons and daughters.

The ECLS-B survey over-sampled twins and so is potentially very useful for this purpose. Unfortunately, perhaps anticipating that twins would be treated equally, the questions on time inputs were not asked separately for each twin. However, it is possible to examine twin differences in time inputs for fraternal twins for the U.K., as the MCS preference questions were asked for each twin. The MCS does not over-sample twins, however, so we are limited to 84 twin pairs in the first wave; 64 pairs in the second wave.

Estimates of inter-twin differences in the parent time inputs in the MCS at age 3 appear in table 9. Our control variables difference out in these regressions since they are common to each

\footnotetext{
12 The MCS survey does not have a corresponding set of questions. There is a question in the first (9 months) sweep asking the mother if the pregnancy was planned. The estimated parameter on the male dummy for this variable is -0.007 (0.007).

${ }^{13}$ These studies typically compare same sex fraternal twins to similarly sex identical twins. There is also a growing literature on violations of the equal environment assumption (see Conley et al. 2013 for a discussion). Many of the documented violations are in environments twins experience as older children and as adults.
} 
twin. For most of the activities the activity levels are lower for the twins than for their full sample counterparts (table 7). The boy-girl differences, while in some cases marginally smaller, are of the same sign as in the full sample, and statistically significant for singing. Also, the difference in the incidence of teaching the alphabet is a statistically insignificant 4.7 percentage points in favor of girls, a point estimate that matches the full sample estimate of 5.5 percentage points well. These results provide some evidence that even across opposite-sex fraternal twins, boys receive less of time inputs such as reading and the teaching of letters and numbers.

Our final investigation of parental preferences is more nuanced: parents may not strictly prefer girls or boys, but have different expectations for them and therefore tailor their time investment accordingly. For example, if parents have greater aspirations for their daughter's or son's academic success, they may invest more heavily in these teaching activities. We examine this possibility using the MCS that asks parents for their opinions of how children should be treated in the first sweep when the children are age 9 months, and about their expectations for their children in the second sweep when the children are 3 years old.

The questions about how children should be treated ask parents to record their agreement with a statement on a five point scale ranging from strongly agree to strongly disagree. Because "can't say" is coded as a $6^{\text {th }}$ response separate from indifference, we recode the variable as $0 / 1$ where 1 equals agree or strongly agree so we can use all responses. ${ }^{14}$ The questions about expectations list 7 qualities their children might possess that parents are asked to rank as the top three and least important. As a summary we code each as 0/1 indicating the respondent thought the given quality the most important. Finally, in this same sweep there are $0 / 1$ variables asking whether it important to instill a given value in the child.

\footnotetext{
${ }^{14}$ The $6^{\text {th }}$ category of not knowing does not have an obvious relative placement in the 5 point scale.
} 
The analysis of these variables is presented in table 10. In the first panel are the responses for how children should be treated at 9 months. There is a slight tendency for more agreement with each treatment if the child is a boy, but the differences are very small and none is statistically significant in the conditional means. The second panel contains the results for older children. With the exception of religious values, parents seek to instill the other canvassed values equally in girls and boys. For the most important qualities, working hard is viewed as a more important quality for boys than girls, while learning religious values is again viewed as more important for girls than boys.

Many of the values and qualities in table 10 are in the social rather than cognitive sphere. They could tell us whether parents put a greater emphasis on social skills for boys, which might account for the lower levels of the cognitive teaching activities that they receive. There is little evidence, however, of this sort of substitution. Also, doing well at school is seen as equally important for girls and boys, so there is no support for a story where parents teach boys less because they expect less of them when they enter the educational system

We have investigated parents' preferences for girls and boys from a number of perspectives. There is little in our results to suggest that parents simply prefer girls or boys, or have substantially different expectations for them, at the ages under study. At the young ages when a boy-girl differential in teaching time emerges, parent preferences do not appear yet to play a role. This evidence refines previous findings of son preference (e.g., Kohler et al. 2005, Dahl and Moretti 2008 and Lundberg et al. 2007) across children in a wider age range. 5.2 Variation in the Boy-Girl Difference in Reading Time by Mothers' Characteristics

We next investigate variation in the boy-girl difference in parents' teaching time by maternal characteristics. We intend this exercise to shed light on the impact of factors external to 
the child, such as the opportunity cost of mothers' time, conditional on any boy-girl difference in production functions. The identification assumption therefore is that the characteristics we examine are not correlated with girl-boy differences in the production function.

We focus on the time spent reading. There is a boy-girl differential for this input in each country that emerges when children are very young. We restrict our attention to samples of children aged more than 1 year, because maternity leave entitlements vary significantly across our countries, from 0-3 months in the U.S. to 12 months in Canada. Maternity leave is an obvious confounding factor that complicates the comparison across countries from samples of children aged less than one year.

The results are reported in table 11 . We compare estimates of the dummy variable for males, across samples divided by the characteristic indicated in the first column. In the first panel is the split by education: mothers with a high school diploma or less and all other mothers. For the U.K. we define high school graduation as completion of the General Certificate of Secondary Education, or O-levels for older cohorts of mothers.

The estimates for Canada and the U.S. provide consistent evidence of a larger boy-girl differential among children of more educated mothers. In the U.K. the inference is the reverse, the larger differential now for mothers with at most a high school diploma. This may reflect North American versus U.K. differences in the meaning of high school completion or more generally of educational attainment in these cohorts of women. The results for Canada and the U.S. are consistent with a larger boy-girl gap in households where mother's time has a higher labor market opportunity cost.

For each country the standard errors do not allow rejection of the hypothesis that the estimates for the different groups of mothers are the same. This will be true for each of our 
comparisons and we instead look for consistency in the patterns across countries as a check against spurious inference.

In the second panel we split the sample by mother's employment. Here a comparison of the results across countries is complicated by differences in maternal employment. In our samples maternal employment varies considerably across countries from a high of over 70 percent in Canada to lows of 57 and 55 percent in the U.K. and U.S. respectively. ${ }^{15}$

In Canada the boy-girl difference is largest for mothers working full time and smallest for mothers who do not work. In the U.K., the boy-girl difference is largest for mothers who work part time or don't work, although here the differences across groups are modest. In the U.S. the difference is greatest for mothers who do not work, although again the differences across groups are fairly modest.

The third panel contains the results by mothers' marital status. Rates of out of wedlock birth are fairly similar between the U.S. and the U.K., but up to 33 percent lower in Canada (Ventura 2009). Nevertheless there is a very consistent story across the three countries. The boygirl difference is largest in households where the child is under the care of two cohabitating adults. The difference is consistently lower in single parent households and households with married parents.

There is a fairly large literature on the outcomes of children whose parents cohabitate. There is consensus that these children have worse outcomes than children whose parents are married, although perhaps less consensus on the size of the effect (e.g., McLanahan and Sandefur 1994, Acs 2007). Weiss (1997) identifies four important functions of marriage-division of labor, coordination of credit and investment, sharing of public goods and risk pooling —all of

${ }^{15}$ See also OECD (2012). 
which may promote investment in any children. He also points out that a durable relationship is needed to fully utilize these functions, and together with the legal costs of dissolving a marriage, they may help account for the greater stability of married unions. Certainly researchers have emphasized the instability of cohabiting relationships which may lead to less cooperative behavior between parents (e.g., Bjorkland et al. 2010), less bargaining power for women (e.g., Rangel 2006) and greater stress (e.g., Artis 2007). Finally, it is widely recognized the any association of outcomes with cohabitation may be the result of selection of certain adults into the state rather than causal.

Factors such as higher stress in cohabitating relationships or less cooperative behavior might account for relatively less reading to boys if there is a higher opportunity cost to do so. Note that a more nuanced selection argument would be needed here because it is not lower or higher amounts of time reading in cohabitating relationships that is at issue. Rather it is the relative rates of reading to girls and boys by relationship status.

An alternative hypothesis for any of the results in table 11 is a boy-girl difference in production functions that engenders relatively lower levels of reading from parents and varies systematically with the different characteristics. This seems a harder case to make, as the maternal characteristics associated with higher boy-girl differentials do not blend easily into a single coherent profile.

\subsection{Time Inputs and Test Scores}

In this last section, we attempt to calibrate the possible consequences of our findings by investigating whether the difference in parental time inputs across girls and boys can account for the boy-girl differences in measures of cognitive development presented in table 1 . In other 
words, we attempt to see if these differences in cognitive inputs potentially matter for test scores that are predictive of later-life success. Price (2012) reports that differences in parents' reading time with children across birth order has power accounting for corresponding birth order effects in children's standardized reading test scores (see also Black et al. 2005). It is important to acknowledge, however, that these scores are likely not a comprehensive summary of the development promoted by parents' time, and that measuring the cognitive development of young children is known to be challenging. ${ }^{16}$

Our strategy is to first regress each cognitive score on our standard control variables as per equation (1). We then add the measures of the parental time inputs $(A C T)$ the child received from his or her parents at younger ages. Each activity is entered as dummy variables representing the different levels of frequency. The equation estimated is

$$
\text { (3) } y_{i}=X \beta+\varphi M_{i}+A C T_{i} \kappa+\varepsilon_{i} \text {. }
$$

We then compare the estimates of the parameters on the dummy variable for male children in the two specifications. To interpret the results of these regressions causally relies on an assumption that the parents' reports of the activities are in fact capturing inputs and not alternative measures of some latent outcome that our cognitive scores are also measuring. This assumption is more compelling when the inputs of parental activities are measured at ages prior to the cognitive tests. Also, the working assumption in these regressions is that time inputs are equally productive for girls and boys. ${ }^{17}$

We examine each of the cognitive measures reported in table 1. In the ECLS-B data these are math and reading scores that are recorded in wave 3 when the children are roughly four years

\footnotetext{
16 See, for example, Bradley-Johnson (2001) and Saye (2003).

17 The alternative assumption is that the time inputs are differentially productive for girls and boys. An obstacle to testing this hypothesis is unobserved factors in both the girls and boys test score "production function" that lead to biased estimates of the parameters on the time inputs. See Todd and Wolpin (2003) for a discussion of the issues.
} 
of age, and are formulated specially for this survey. Each measure draws on well-known cognitive tests such as the Peabody Picture Vocabulary Test (PPVT) and the Test of Early Mathematics Ability-3. ${ }^{18}$ In the NLSCY we have PPVT scores and scores on the Know Your Numbers (KYN) test, both administered at ages 4 and 5. In the MCS are Picture Similarity, Pattern Construction and Naming Vocabulary test scores. ${ }^{19}$ These are subscales of the British Ability Scales, Second Edition. As documented in table 1, there are systematic sex differences in almost all of these developmental tests.

The analysis of the ECLS-B data is in table 12, in the top panel. Because the sample of four and five year olds with valid observations on parents' time inputs from previous waves does not exactly match the full sample of four and five year olds with valid test scores in round 3, the estimates of sex gaps in the test scores conditional on our standard control variables in the first column do not exactly match the estimates in table $1 .{ }^{20}$ That said, the differences are quite small. In the second column of each row is the estimated sex difference for the indicated score when we also control for the parental inputs reported in table 6. In each case the estimated sex difference is smaller once the additional controls for inputs are added. The most substantial reductions are for the inputs measured at age 2. The addition of the input variables reduces the sex difference in reading scores by 23 percent and the sex difference in the math score by 25 percent.

Corresponding analysis of the NLSCY data is in the middle panel of table 12. Recall the NLSCY canvases a more extensive set of inputs, a number of which focus on specific learning activities (e.g., teaching new words or numbers). Also, the NLSCY has a more complex longitudinal structure, with multiple cohorts whose aging across waves of the survey does not

\footnotetext{
${ }^{18}$ A listing and discussion of the tests the instrument are based on can be found in The ECLS-B Direct Assessment Choosing the Appropriate Score for Analysis at nces.ed.gov/ecls/pdf/birth/ChoosingScores.pdf

${ }^{19}$ We use the "ability" rather than "raw" versions of these test scores.

${ }^{20}$ This is also true for the NLSCY and MCS.
} 
perfectly match the age cutoffs for the questions about specific inputs. ${ }^{21}$ As in the U.S. data, controlling for the gender differences in inputs at very young ages has a rather modest impact on the gender gap in scores. The inputs measured at older ages have a larger impact, reducing the gap in PPVT by 36 percent and in Know Your Numbers scores by roughly 50 percent.

Finally the results for the U.K. data are in the bottom panel of the table. Here we relate cognitive scores at age 5 to parents' time inputs at age 3 . Adding the inputs reduces the gender gap in both the Picture Similarity score and the Pattern Construction score by 16 and 23 percent respectively. The reduction in the Naming Vocabulary score is much larger, but for this score the gender gaps are statistically insignificant.

\subsection{Conclusions}

We re-examine and extend the literature on how parental time inputs differ across girls and boys. Our focus is children at preschool ages. We first offer a refinement of evidence in previous studies that boys receive more parental time than girls due to extra time input from their fathers. We show that this higher time input from fathers only emerges with age, and is not present when children are very young. We next examine specific parental time inputs that are related to teaching, rather than the general categories of time that have been studied in the past. This change in focus leads to a significant change in inference. It is girls, not boys, who systematically, in three developed countries, receive more of these time inputs from their parents. The inputs examined include reading, storytelling, and teaching letters and numbers.

We attempt to discover what lies behind this difference in parental time between girls and boys. Our most compelling evidence is that the boy-girl differences are not due to a direct

\footnotetext{
${ }^{21}$ For example, in their second interview a cohort of children will be ages 2 and 3 , and so half we will have responses for the age 0-2 inputs and half will have responses for the age 3-5 inputs.
} 
preference of parents for children of a specific sex. We show that parents do not express a preference for children of a specific sex at the ages the sex difference in parental inputs emerge, that it is evident despite any desire of parents to treat fraternal twins similarly, and that parents due not express any different expectations for their girls and boys that might account for our findings.

We also demonstrate that the gender differences in parental inputs are correlated with a number of mothers' characteristics, some of which can be interpreted as proxies for the opportunity cost of time. We interpret this as evidence of sensitivity of the sex difference to change in the cost of the time inputs, conditional on any sex differences in production functions. An alternative explanation, that there are boy-girl differences in production functions that vary systematically in the different dimensions we document, does not yield a coherent profile of mothers who might have boys who are relatively less responsive to reading inputs at these ages.

Finally we show that these boy-girl differences in parental inputs can account for some part of corresponding differences in their preschool cognitive scores. While the latter are relatively modest, the tests are recorded at young ages, and so the impact may cumulate at older ages if learning deficits and advantages are cumulative. Furthermore, we are limited in our data to connect the boy-girl differential in time inputs to early childhood cognitive scores, while these inputs may have impacts on a wider range of outcomes. For example, parental teaching may embed behavior patterns that children need to excel at school. Therefore, the boy-girl differences we document may contribute to the male deficit in non-cognitive skills that has been linked to problems at higher grades (Bertrand and Pan 2013, Cornwell et al. 2013, Jacob 2002). They may also precipitate patterns in children's own use of time at older ages. 


\section{Data Appendix}

\section{U.S. Data}

ATUS: Each household has one respondent who answers the time-use questions, so we have either a mother or a father from each household, but never both in the sample. We draw a sample of oldest children aged zero to five. We include own children in and outside the household. For the regressions, we include controls for age (single year), mother's / father's age (five year groups), mother's / father's education (four categories), mother's / father's foreign birth, region, race (black and Hispanic), survey year, survey month, and diary day.

$E C L S-B$ : For the regressions we include controls for age (single month), birth state, mother's age (single year), education, foreign birth and indicators for whether the mother is black or Hispanic. NSFG: The information on children is built up from the pregnancy histories of the surveyed women. The analysis makes use of recoded variables provided in the NSFG but omits observations with imputed values of these variables. The control variables for the NSFG regressions include dummies for mother's age at conception, child's age, child's month and year of birth, mothers' education, ethnicity (black, Hispanic), religion (catholic, protestant, none), foreign birth and rural location.

\section{Canadian Data}

MES: The survey excludes mothers living on Indian Reserves or collective dwellings. There is no imputation of variables in the MES. The control variables in the MES regression are child's age (single year), mother's age (single year), and dummy variables for mother's education (4 categories), aboriginals, province and rural residence.

NLSCY: In each biennial survey, new cohorts of children aged 0 and 1 enter the survey. These cohorts are interviewed again at ages $2 / 3$ and $4 / 5$. Not all children are captured in later surveys 
due to attrition, or for some cohorts by design. Other cohorts receive top up samples at ages $2 / 3$ and 4/5. The control variables for the regressions are child's age (single year), mother's age (five year age groups), mother's education, mother's foreign birth, dummy variables for province, urban size (5 categories) and year of birth.

\section{United Kingdom Data}

$M C S$ : The control variables for the regressions are education, child's age at time of survey (single month), mother's age at birth (single year), country of birth and ethnicity (Chinese, other Asian, black). At Age 3 the reading question is coded 1) every day, 2) several times a week, 3) once or twice a week, 4) once or twice a month, 5) less often and 6) not at all. The questions about library trips is coded 1) on special occasions, 2) once a month, 3) once a fortnight and 4) once a week. The remaining questions are coded 1) occasionally or less than once a week, 2) 1-2 days per week 3) 3 times per week, 4) 4 times per week, 5) 5 times per week, 6) 6 times per week and 7) 7 times per week/constantly. At age 5 all activities are coded are coded 1) every day, 2) several times a week, 3) once or twice a week, 4) once or twice a month, 5) less often and 6) not at all except library trips that are coded 1) every day or almost every day, 2) several times a week, 3) once or twice a week, 4) at least once a month, 5) every few months, 6) at least once a year, 7) less often or never.

\section{Identifying the First Born}

In each data set we identify the first born as directly as possible given the questions available in the survey. Where alternative strategies are available we have investigated them. In these cases the sex differences reported in the paper are not sensitive to the method we use to identify the first born. This is due to the fact that they are also present for higher parity children. 
ATUS: The first born is identified based on the family structure reported. We label the oldest 'own' child as the first born

$E C L S-B$ : The first born is identified according to the number of previous live births the mother has had taken from the birth certificate.

NSFG: The first born is identified as the child from the mother's first pregnancy that resulted in a singleton live birth.

MES: The first born is identified by a question answered by the mother about any previous live births.

NLSCY: The first born is identified based on the family structure (i.e., absence of older siblings in the household) recorded in the child's first survey (at ages 0-1).

$M C S$ : The first born is identified by information on the structure of the family at the first survey (any siblings present) and a question answered by the mother on any previous live births. 


\section{References}

Acs, G. (2007), "Can we promote child well-being by promoting marriage?", Journal of Marriage and Family, 69(5), 1326-44.

Artis, J. E. (2007), "Maternal cohabitation and child well-being among kindergarten children", Journal of Marriage and the Family, 69, 222-36.

Abrevaya, J., (2009) "Are there missing girls in the United States? Evidence from birth data", American Economic Journal: Applied Economics, 1(2), 1-34.

Aizer, Anna and Flavio Cunha (2012), "The Production of Child Human Capital: Endowments, Investments, and Fertility,” NBER Working Paper No. 18429.

Almond, D. and J. Currie, (2011) "Human Capital Development Before Age Five" in Orley Ashenfelter and David A. Card (eds.) Handbook of Labor Economics Vol. 4, Part 2,. Amsterdam: Elsevier, 1315-1485

Almond, Douglas, Edlund, Lena and Kevin Milligan, (2013) "Son Preference and the Persistence of Culture: Evidence from South and East Asian Immigrants to Canada," Population and Development Review, March 2013.

Angrist, J. and W.N Evans, (1998) "Children and Their Parents Labor Supply: Evidence from Exogenous Variation in Family Size," American Economic Review 88, 450-477.

Barcellos, I.H., Carvalho, L. and A. Lleras-Muney, (2012) "Child Gender and Parental Investments in India: Are Boys and Girls Treated Differently?" NBER Working Paper No. 17781.

Becker, Gary and Nigel Tomes, (1976), "Child Endowments and the Quantity and Quality of Children," Journal of Political Economy, 84, S143-62.

Becker, Gary and Nigel Tomes (1986): "Child endowments and the quantity and quality of children," Journal of Political Economy, 84(4), S143-S162.

Bertrand, Marianne and Jessica Pan, (2013) "The Trouble with Boys: Social Influences and the Gender Gap in Disruptive Behavior", American Economic Journal: Applied Economics, $5(1), 32-64$.

Björklund, Anders, Ginther, Donna K. and Marianne Sundström, (2010), "Does Marriage Matter for Children? Assessing the Impact of Legal Marriage in Sweden," Swedish Institute for Social Research, Stockholm University, Working Paper 3/2010.

Black, Sandra, E., Devereux, Paul and Kjell Salvanes, (2005) "The More the Merrier? The Effect of Family Size and Birth Order on Children's Education" Quarterly Journal of 
Economics, May 2005.

Borooah, Vani K. (2004) "Gender bias among children in India in their diet and immunization against disease." Social Science and Medicine 58(9), 1719 - 1731.

Bradley-Johnson, Sharon (2001) "Cognitive Assessment for the Youngest Children: A Critical Review of Tests" Journal of Psychoeducational Assessment, 19, 19-44.

Bryant, W. Keith and Cathleen D. Zick (1996) "An Examination of Parent-Child Shared Time", Journal of Marriage and the Family, 58, 227-237.

Conley, Dalton Emily Rauscher, Christopher Dawes, Patrik K. E. Magnusson, and Mark L. Siegal (2013) "Heritability and the Equal Environments Assumption: Evidence from Multiple Samples of Misclassified Twins," Behavior Genetics, 43(5), 415-426.

Cornwell, Christopher, David B. Mustard, and Jessica Van Parys, (2013) "Noncognitive Skills and the Gender Disparities in Test Scores and Teacher Assessments: Evidence from Primary School" The Journal of Human Resources, 48(1), 238-266.

Dahl, G.B. and E. Moretti, (2008) "The Demand for Sons." Review of Economic Studies, 75(4), 1085-1120.

Das Gupta, M. (1987) "Selective discrimination against female children in rural Punjab, India." Population and Development Review, 13(1), 77-100.

Farah, Martha J., Betancourt Laura, Shera David M., Savage Jessica H., Giannetta Joan M., Brodsky Nancy L. and Elsa K. Malmud, (2008), "Environmental stimulation, parental nurturance and cognitive development in humans" Developmental Science, 11(5), 793801.

Fryer, R.G., and S.D. Levitt, (2010) "An Empirical Analysis of the Gender Gap in Mathematics" American Economic Journal: Applied Economics, 2(2), 210-40.

Ganatra, B. and S. Hirve. (1994) "Male bias in health care utilization for under-fives in a rural community in western India." Bulletin of the World Health Organization, 72(1), 101-104.

Guryan, Jonathan, Erik Hurst and Melissa Kearney, (2008) "Parental Education and Parental Time with Children", The Journal of Economic Perspectives, 22(3), 23-46.

Halpern, Diane F. (2011) Sex Differences in Cognitive Abilities Fourth Edition, New York: Psychology Press.

Jacob, Brian A. (2002) "Where the boys aren't: non-cognitive skills, returns to school and the gender gap in higher education," Economics of Education Review, 21, 589-598. 
Jayachandran, S. and Kuziemko, I. (2011) "Why Do Mothers Breastfeed Girls Less than Boys: Evidence and Implications for Child Health in India," Quarterly Journal of Economics, 126(3), 1485-1538.

Kalb, Guyonne and Jan C. van Ours (2013), "Reading to Young Children: A Head-Start in Life?” IZA Discussion Paper No. 7416.

Kohler, Hans-Peter, Behrman, Jere R. and Axel Skytthe, (2005) "Partner + Children = Happiness? The Effects of Partnerships and Fertility on Well-Being," Population and Development Review, 31(3), 407-445.

Lundberg, S. (2005a) “Sons, Daughters and Parental Behavior”, Oxford Economic Papers, 21(3), 340-356.

Lundberg, S. (2005b), “The Division of Labor by New Parents: Does Child Gender Matter?” IZA Discussion Paper No. 1787 September.

Lundberg, S., S.W. Pabilonia and J. Ward-Batts, (2007) “Time Allocation of Parents and Investments in Sons and Daughters." Working paper. Department of Economics, University of Washington.

Lundberg, S. and E. Rose, (2002) “The Effects of Sons and Daughters on Men's Labor Supply and Wages", Review of Economics and Statistics, 84(2), 251-268.

McLanahan, S., and Sandefur, G. (1994). Growing up with a single parent: What hurts, what helps. Cambridge MA: Harvard University Press.

McDougall, J. DeWit D.J. and G.E. Ebanks, (1999) "Parental Preferences for Sex of Children in Canada“, Sex Roles, 41(7/8), 615-626.

Medland, S. and Hatemi, P. (2009). Political science, biometric theory, and twin studies: A methodological introduction. Political Analysis, 17, 191-214.

OECD (2012) Family database, LMF1.2: Maternal employment rates Social Policy Division Directorate of Employment, Labour and Social Affairs, (www.oecd.org/social/family/database)

Paxson, Christina and Norbert Schady (2007): "Cognitive Development Among Young Children in Ecuador: the Roles of Wealth, Health and Parenting." Journal of Human Resources, $52(1), 49-84$.

Pollack, Robert A. and Michael L. Wachter, (1975), "The Relevance of the Household Production Function and Its Implications for the Allocation of Time", Journal of Political Economy, 83(2), 255-277.

Price, Joseph. (2008) “Parent-Child Quality Time Does Birth Order Matter?”, Journal of Human 
Resources 43(1), 240-265.

Price, Joseph. (2012) "The effects of parental time investments: Evidence from natural withinfamily variation." BYU Working Paper.

Raley, S. and S. Bianchi (2006) "Sons, Daughters, and Family Processes: Does Gender of Children Matter?" Annual Review of Sociology, 32, 401-421.

Ramey, Gary and Valerie A. Ramey (2010), “The Rug Rat Race,” Brookings Papers on Economic Activity, Spring, 126-176.

Rangel, M. A. (2006), 'Alimony rights and intrahousehold allocation of resources: evidence from Brazil', Economic Journal, 116, 627-58

Rosin, Hanna, (2012) The End of Men and the Rise of Women, New York: Penguin.

Saye, Kimberley B. (2003) "Preschool intellectual assessment”. In: Reynolds Cecil R, Kamphaus Randy W, (eds.) Handbook of Psychological and Educational Assessment of Children, 2nd edition. New York: Guilford, 87-203.

Sayer, Liana, Suzanne Bianchi, and John Robinson. 2004. "Are Parents Investing Less in Children? Trends in Mothers' and Fathers' Time with Children." American Journal of Sociology, 110(1), 1-43.

Todd, Petra E. and Kenneth I. Wolpin, (2003), "On the Specification and Estimation of the Production Function for Cognitive Achievement", The Economic Journal, 113, F3-F33

Ventura SJ., "Changing patterns of nonmarital childbearing in the United States." NCHS data brief, no 18. Hyattsville, MD: National Center for Health Statistics. 2009.

Yeung, W.J., J.F. Sandberg, P.E. Davis-Kean, and S.L. Hofferth. (2001) "Children's Time With Fathers in Intact Families. Journal of Marriage and Family 63, 136-54.

Weiss, Y. (1997), "The Formation and Dissolution of Families: Why Marry, Who Marries Whom, and What Happens Upon Marriage and Divorce?" in Rosenzweig, M. and O. Stark (eds.) Handbook of Population Economics, Elsevier, 81-123.

Zick, Cathleen D. and W. Keith Bryant (1996) "A new look at parents' time spent in child care: Primary and secondary time use.” Social Science Research 25(3), 260-280. 
Table 1: Sex differences in Selective Cognitive Tests at ages 4-5

\begin{tabular}{lccc}
\hline & Males & Females & $\begin{array}{c}\text { Conditional } \\
\text { Difference }\end{array}$ \\
\hline US & & & $-1.851^{* * *}$ \\
Reading Score & 25.66 & 27.60 & $\begin{array}{c}(0.454) \\
\text { Math Score }\end{array}$ \\
& 29.54 & 30.88 & $\begin{array}{c}-1.227^{* * *} \\
(0.390)\end{array}$ \\
\hline Canada & & & \\
\hline PPVT & 101.32 & 103.52 & $-2.773^{* * *}$ \\
& & & $(0.832)$ \\
Number Knowledge & 1.227 & 1.268 & $-0.066^{* *}$ \\
Score & & & $(0.028)$ \\
\hline UK & & 83.09 & $-1.692^{* * *}$ \\
\hline $\begin{array}{l}\text { Picture Similarity } \\
\text { Score }\end{array}$ & & & $(0.338)$ \\
Naming Vocabulary & 110.57 & 111.46 & -0.608 \\
Ability Score & & & $(0.416)$ \\
Pattern Construction & 87.27 & 89.96 & $-2.777^{* * *}$ \\
Ability Score & & & $(0.533)$ \\
\hline
\end{tabular}

Notes: Authors' calculations from the U.S. ECLS-B, the Canadian NLSCY and U.K. MCS. Reported in the first two columns are the unconditional means of each test score for the samples of male and female children. The third column reports the estimated coefficient on the male binary indicator in a regression including the control variables described in the appendix. Robust standard errors in parentheses. One star indicates significance at the 10 percent level; two stars for 5 percent; three stars for 1 percent. 
Table 2: Sex Differences in Parents' Time Inputs in the United States-First Born

\begin{tabular}{|c|c|c|c|}
\hline & Males & Females & $\begin{array}{l}\text { Conditional } \\
\text { Difference }\end{array}$ \\
\hline \multicolumn{4}{|l|}{ Age 2 and Younger } \\
\hline \multicolumn{4}{|l|}{ Mothers } \\
\hline Primary care time & 165.4 & 164.5 & $\begin{array}{c}2.2 \\
(5.9)\end{array}$ \\
\hline Secondary care & 407.1 & 400.5 & $\begin{array}{c}4.3 \\
(11.2)\end{array}$ \\
\hline Physical care & 86.5 & 89.0 & $\begin{array}{l}-1.5 \\
(4.2)\end{array}$ \\
\hline Play and Sports & 57.9 & 56.5 & $\begin{array}{l}1.7 \\
(3.8)\end{array}$ \\
\hline \multicolumn{4}{|l|}{ Fathers } \\
\hline Primary care time & 94.7 & 88.4 & $\begin{array}{c}6.3 \\
(7.1)\end{array}$ \\
\hline Secondary care & 263.0 & 264.9 & $\begin{array}{c}2.6 \\
(11.9)\end{array}$ \\
\hline Physical care & 41.8 & 37.9 & $\begin{array}{c}2.7 \\
(5.0)\end{array}$ \\
\hline Play and Sports & 43.1 & 37.5 & $\begin{array}{c}6.7 \\
(4.9) \\
\end{array}$ \\
\hline \multicolumn{4}{|l|}{ Age 3-5 } \\
\hline \multicolumn{4}{|l|}{ Mothers } \\
\hline Primary care time & 125.5 & 126.4 & $\begin{array}{l}-0.6 \\
(4.4)\end{array}$ \\
\hline Secondary care & 406.3 & 402.6 & $\begin{array}{l}4.8 \\
(9.5)\end{array}$ \\
\hline Physical care & 52.5 & 56.6 & $\begin{array}{l}-4.1 \\
(2.3)\end{array}$ \\
\hline Play and Sports & 39.0 & 37.9 & $\begin{array}{c}1.5 \\
(2.7)\end{array}$ \\
\hline \multicolumn{4}{|l|}{ Fathers } \\
\hline Primary care time & 84.8 & 77.9 & $\begin{array}{c}7.2 \\
(5.1)\end{array}$ \\
\hline Secondary care & 265.8 & 235.3 & $\begin{array}{r}24.1^{* *} \\
(10.3)\end{array}$ \\
\hline Physical care & 25.8 & 26.4 & $\begin{array}{l}-0.9 \\
(2.3)\end{array}$ \\
\hline Play and Sports & 42.8 & 32.4 & $\begin{array}{c}10.6^{* * * *} \\
(3.8)\end{array}$ \\
\hline
\end{tabular}

Notes: Authors' calculations from ATUS data. Reported in the first two columns are the unconditional means of each dependent variable for the samples of male and female children. The third column reports the estimated coefficient on the male binary indicator in a regression including the control variables described in the appendix. Robust standard errors in parentheses. One star indicates significance at the 10 percent level; two stars for 5 percent; three stars for 1 percent. 
Table 3: Sex Differences in Parents' Time Inputs in Canada-First Born

\begin{tabular}{lccc}
\hline & Males & Females & $\begin{array}{c}\text { Conditional } \\
\text { Difference }\end{array}$ \\
\hline Age 4-5 & & \\
\hline Mothers & & 5.818 & -0.045 \\
\hline $\begin{array}{l}\text { Frequency of eating } \\
\text { with child }\end{array}$ & 5.773 & 4.847 & $0.035)$ \\
$\begin{array}{l}\text { Frequency of playing } \\
\text { with child }\end{array}$ & 4.884 & 5.927 & $(0.065)$ \\
$\begin{array}{l}\text { Frequency of talking } \\
\text { with child }\end{array}$ & 5.120 & 4.815 & -0.015 \\
$\begin{array}{l}\text { Frequency of doing } \\
\text { chores with child }\end{array}$ & 4.824 & & $-0.020)$ \\
$\begin{array}{l}\text { Frequency of outings } \\
\text { with child }\end{array}$ & 4.065 & 4.075 & $(0.066)$ \\
\hline $\begin{array}{l}\text { Fathers } \\
\text { Frequency of eating } \\
\text { with child }\end{array}$ & 5.337 & & -0.017 \\
$\begin{array}{l}\text { Frequency of playing } \\
\text { with child }\end{array}$ & 4.428 & 5.348 & $(0.058)$ \\
$\begin{array}{l}\text { Frequency of talking } \\
\text { with child }\end{array}$ & 5.608 & 4.213 & -0.006 \\
$\begin{array}{l}\text { Frequency of doing } \\
\text { chores with child }\end{array}$ & 3.723 & 5.549 & $0.243 * * *$ \\
$\begin{array}{l}\text { Frequency of outings } \\
\text { with child }\end{array}$ & 3.479 & 3.635 & $(0.077)$ \\
\hline
\end{tabular}

Notes: Authors' calculations from NLSCY data. Sample includes children aged 4 and 5.

Reported in the first two columns are the unconditional means of each dependent variable for the samples of male and female children. The third column reports the estimated coefficient on the male binary indicator in a regression including the control variables described in the appendix. Robust standard errors in parentheses. One star indicates significance at the 10 percent level; two stars for 5 percent; three stars for 1 percent. 
Table 4: Maternal Care Post Birth and Mothers' Return to Work - First Born

\begin{tabular}{|c|c|c|c|}
\hline & Males & Females & $\begin{array}{l}\text { Conditional } \\
\text { Difference }\end{array}$ \\
\hline \multicolumn{4}{|c|}{ ECLS-B: 9 months (and 2 years*) } \\
\hline $\begin{array}{l}\text { Maternal Care first } 6 \\
\text { months }\end{array}$ & 4.277 & 4.325 & $\begin{array}{l}-0.056 \\
(0.083)\end{array}$ \\
\hline $\begin{array}{l}\text { Maternal Care first } 16 \\
\text { months* }\end{array}$ & 7.754 & 7.716 & $\begin{array}{c}0.005 \\
(0.260)\end{array}$ \\
\hline Mother returned to Work & 0.642 & 0.651 & $\begin{array}{l}-0.000 \\
(0.020)\end{array}$ \\
\hline $\begin{array}{l}\text { Months Since Birth at } \\
\text { Return }\end{array}$ & 4.086 & 4.068 & $\begin{array}{l}-0.011 \\
(0.086)\end{array}$ \\
\hline \multicolumn{4}{|l|}{ MES Age 5-15 Months } \\
\hline Returned to work & 0.122 & 0.131 & $\begin{array}{l}-0.005 \\
(0.013)\end{array}$ \\
\hline Weeks since birth at return & 18.845 & 19.457 & $\begin{array}{c}-2.029 * * \\
(1.021)\end{array}$ \\
\hline \multicolumn{4}{|l|}{ MCS Age 9 months } \\
\hline $\begin{array}{l}\text { Mother Returned to work } \\
\text { (conditional on previously } \\
\text { working) }\end{array}$ & 0.986 & 0.983 & $\begin{array}{c}0.002 \\
(0.004)\end{array}$ \\
\hline Mother currently working & 0.508 & 0.503 & $\begin{array}{c}0.010 \\
(0.012)\end{array}$ \\
\hline $\begin{array}{l}\text { Mother takes care of } \\
\text { home/children }\end{array}$ & 0.427 & 0.431 & $\begin{array}{l}-0.013 \\
(0.011)\end{array}$ \\
\hline
\end{tabular}

Notes: Authors' calculations from ECLS-B, MES and MCS data. Reported in the first two columns are the unconditional means of each dependent variable for the samples of male and female children. The third column reports the estimated coefficient on the male binary indicator in a regression including the control variables described in the appendix. Robust standard errors in parentheses. One star indicates significance at the 10 percent level; two stars for 5 percent; three stars for 1 percent. 
Table 5: Parental Time Inputs Promoting Cognition, United States-First Born

Males $\quad$ Females Conditional

Difference

\begin{tabular}{|c|c|c|c|}
\hline \multicolumn{4}{|l|}{9 Months } \\
\hline Read Stories & 2.782 & 2.880 & $\begin{array}{c}-0.083 * * \\
(0.041)\end{array}$ \\
\hline Tell Stories & 2.578 & 2.597 & $\begin{array}{l}-0.010 \\
(0.047)\end{array}$ \\
\hline Sing Songs & 3.635 & 3.687 & $\begin{array}{l}-0.046 \\
(0.028)\end{array}$ \\
\hline Errands & 3.511 & 3.523 & $\begin{array}{c}-0.012 \\
(0.023) \\
\end{array}$ \\
\hline \multicolumn{4}{|l|}{2 Years } \\
\hline Read Stories & 3.152 & 3.283 & $\begin{array}{c}-0.118 * * * \\
(0.034)\end{array}$ \\
\hline Tell Stories & 2.659 & 2.749 & $\begin{array}{c}-0.098 * * \\
(0.045)\end{array}$ \\
\hline Sing Songs & 3.520 & 3.638 & $\begin{array}{c}-0.098 * * * \\
(0.031)\end{array}$ \\
\hline Errands & 3.531 & 3.490 & $\begin{array}{c}0.038 \\
(0.030)\end{array}$ \\
\hline $\begin{array}{l}\text { Visit Library } \\
\text { Past Month }\end{array}$ & 0.234 & 0.295 & $\begin{array}{c}-0.060 * * * \\
0.020)\end{array}$ \\
\hline $\begin{array}{l}\text { Child Attends } \\
\text { Story Hour }\end{array}$ & 0.115 & 0.126 & $\begin{array}{l}-0.011 \\
(0.014)\end{array}$ \\
\hline Number Books & 39.91 & 44.47 & $\begin{array}{c}-4.145 * * \\
(1.573)\end{array}$ \\
\hline $\begin{array}{l}\text { Number } \\
\text { records/CDs }\end{array}$ & 8.317 & 9.250 & $\begin{array}{c}-1.052 * * * \\
(0.573)\end{array}$ \\
\hline \multicolumn{4}{|l|}{4 years } \\
\hline Read Stories & 3.093 & 3.221 & $\begin{array}{c}-0.119 * * * \\
0.036)\end{array}$ \\
\hline Tell Stories & 2.714 & 2.791 & $\begin{array}{l}-0.059 \\
(0.043)\end{array}$ \\
\hline Sing Songs & 3.245 & 3.459 & $\begin{array}{c}-0.196 * * * \\
(0.038)\end{array}$ \\
\hline $\begin{array}{l}\text { Minutes } \\
\text { Reading }\end{array}$ & 24.52 & 27.80 & $\begin{array}{c}-2.942 * * * \\
(0.930)\end{array}$ \\
\hline $\begin{array}{l}\text { Visit Library } \\
\text { Past Month }\end{array}$ & 0.365 & 0.405 & $\begin{array}{l}-0.041 * \\
(0.022)\end{array}$ \\
\hline $\begin{array}{l}\text { Child Attends } \\
\text { Story Hour }\end{array}$ & 0.298 & 0.331 & $\begin{array}{l}-0.035 \\
(0.035)\end{array}$ \\
\hline Number Books & 65.86 & 70.23 & $\begin{array}{l}-3.274 \\
(3.197)\end{array}$ \\
\hline
\end{tabular}


Notes: Authors' calculations from ECLS-B data. Reported in the first two columns are the unconditional means of each dependent variable for the samples of male and female children. The third column reports the estimated coefficient on the male binary indicator in a regression including the control variables described in the appendix. Robust standard errors in parentheses. One star indicates significance at the 10 percent level; two stars for 5 percent; three stars for 1 percent. 
Table 6: Parental Time Inputs Promoting Cognition, Canada-First Born

\begin{tabular}{|c|c|c|c|}
\hline & Males & Females & $\begin{array}{l}\text { Conditional } \\
\text { Difference }\end{array}$ \\
\hline \multicolumn{4}{|l|}{ Age 0-1 } \\
\hline Play action games & 4.830 & 4.864 & $\begin{array}{l}-0.035^{*} \\
(0.020)\end{array}$ \\
\hline Take on errands & 3.981 & 4.004 & $\begin{array}{l}-0.023 \\
(0.031)\end{array}$ \\
\hline Go on Walks & 4.381 & 4.422 & $\begin{array}{l}-0.047 \\
(0.035)\end{array}$ \\
\hline Read stories & 4.486 & 4.613 & $\begin{array}{c}-0.114 * * * \\
(0.037)\end{array}$ \\
\hline Tell Stories & 4.163 & 4.201 & $\begin{array}{l}-0.025 \\
(0.053)\end{array}$ \\
\hline Sing Songs & 4.699 & 4.732 & $\begin{array}{l}-0.031 \\
(0.029)\end{array}$ \\
\hline Teach new words & 4.619 & 4.702 & $\begin{array}{l}-0.071 * \\
(0.041)\end{array}$ \\
\hline Age exposed to books & 3.899 & 3.817 & $\begin{array}{c}0.079 \\
(0.116)\end{array}$ \\
\hline $\begin{array}{l}\text { How often goes to } \\
\text { library }\end{array}$ & 1.382 & 1.404 & $\begin{array}{l}-0.022 \\
(0.041)\end{array}$ \\
\hline \multicolumn{4}{|l|}{ Age 3-4 } \\
\hline Go on Walks & 4.408 & 4.374 & $\begin{array}{c}0.023 \\
(0.033)\end{array}$ \\
\hline Read books & 4.380 & 4.523 & $\begin{array}{c}-0.162 * * * \\
(0.043)\end{array}$ \\
\hline Tell Stories & 4.487 & 4.595 & $\begin{array}{c}-0126 * * * \\
(0.039)\end{array}$ \\
\hline Sing Songs & 4.313 & 4.524 & $\begin{array}{c}-0.221 * * * \\
(0.043)\end{array}$ \\
\hline $\begin{array}{l}\text { Teach to read new } \\
\text { words }\end{array}$ & 3.382 & 3.368 & $\begin{array}{l}-0.024 \\
(0.074)\end{array}$ \\
\hline $\begin{array}{l}\text { Teach letters and } \\
\text { numbers }\end{array}$ & 3.894 & 4.020 & $\begin{array}{c}-0.137 * * * \\
(0.053)\end{array}$ \\
\hline $\begin{array}{l}\text { Encourage use of } \\
\text { numbers }\end{array}$ & 4.501 & 4.560 & $\begin{array}{l}-0.070^{*} \\
(0.040)\end{array}$ \\
\hline $\begin{array}{l}\text { How often goes to } \\
\text { library }\end{array}$ & 1.933 & 2.025 & $\begin{array}{c}-0.120 * * * \\
(0.042)\end{array}$ \\
\hline
\end{tabular}

Notes: Authors' calculations from NLSCY data. Reported in the first two columns are the unconditional means of each dependent variable for the samples of male and female children. The third column reports the estimated coefficient on the male binary indicator in a regression including the control variables described in the appendix. Robust standard errors in parentheses. 
One star indicates significance at the 10 percent level; two stars for 5 percent; three stars for 1 percent. 
Table 7: Parental Time Inputs Promoting Cognition, U.K. —First Born

\begin{tabular}{|c|c|c|c|}
\hline & Males & Females & $\begin{array}{l}\text { Conditional } \\
\text { Difference }\end{array}$ \\
\hline \multicolumn{4}{|l|}{ Age 3} \\
\hline Reading (mother) & 5.414 & 5.487 & $\begin{array}{c}-0.090 * * * \\
(0.027)\end{array}$ \\
\hline Teach Alphabet & 4.186 & 4.444 & $\begin{array}{c}-0.308 * * * \\
(0.072)\end{array}$ \\
\hline Teach Counting & 6.227 & 6.183 & $\begin{array}{l}-0.030 \\
(0.064)\end{array}$ \\
\hline Teach Songs & 6.238 & 6.576 & $\begin{array}{c}-0.356 * * * \\
(0.061)\end{array}$ \\
\hline Paint (PMK) & 5.328 & 6.372 & $\begin{array}{c}-0.982 * * * \\
(0.004)\end{array}$ \\
\hline $\begin{array}{l}\text { How often goes to } \\
\text { library }\end{array}$ & 1.884 & 1.959 & $\begin{array}{l}-0.064 * \\
(0.036)\end{array}$ \\
\hline \multicolumn{4}{|l|}{ Age 5} \\
\hline Reading & 5.410 & 5.450 & $\begin{array}{l}-0.046^{*} \\
(0.026)\end{array}$ \\
\hline Tell Stories & 3.639 & 3.749 & $\begin{array}{c}-0.142 * * * \\
(0.046)\end{array}$ \\
\hline Musical Activities & 4.829 & 5.081 & $\begin{array}{c}-0.247 * * * \\
(0.034)\end{array}$ \\
\hline Drawing & 3.910 & 4.161 & $\begin{array}{c}-0.266^{* * *} * \\
(0.035)\end{array}$ \\
\hline Play Games & 4.780 & 4.707 & $\begin{array}{c}0.083 * * * \\
(0.033)\end{array}$ \\
\hline Go to Park & 3.834 & 3.793 & $\begin{array}{c}0.041 \\
(0.030)\end{array}$ \\
\hline $\begin{array}{l}\text { How often goes to } \\
\text { library }\end{array}$ & 2.612 & 2.706 & $\begin{array}{c}-0.095 * * \\
(0.043)\end{array}$ \\
\hline
\end{tabular}

Notes: Authors' calculations from MCS data. Reported in the first two columns are the unconditional means of each dependent variable for the samples of male and female children. The third column reports the estimated coefficient on the male binary indicator in a regression including the control variables described in the appendix. Robust standard errors in parentheses. One star indicates significance at the 10 percent level; two stars for 5 percent; three stars for 1 percent. 
Table 8: Parents' Views of the Wantedness and Timing of the Pregnancy-First Born

\begin{tabular}{|c|c|c|c|}
\hline & Males & Females & $\begin{array}{l}\text { Adjusted } \\
\text { Difference }\end{array}$ \\
\hline \multicolumn{4}{|l|}{ US Age 2 and Younger } \\
\hline $\begin{array}{l}\text { Mother: didn't want } \\
\text { pregnancy }\end{array}$ & 0.096 & 0.060 & $\begin{array}{l}0.033 * \\
(0.020)\end{array}$ \\
\hline $\begin{array}{l}\text { Mother: pregnancy at } \\
\text { right time }\end{array}$ & 0.503 & 0.537 & $\begin{array}{l}-0.036 \\
(0.032)\end{array}$ \\
\hline $\begin{array}{l}\text { Partner: didn't want } \\
\text { pregnancy }\end{array}$ & 0.106 & 0.106 & $\begin{array}{l}-0.001 \\
(0.021)\end{array}$ \\
\hline $\begin{array}{l}\text { Partner: pregnancy at } \\
\text { right time }\end{array}$ & 0.529 & 0.527 & $\begin{array}{c}0.007 \\
(0.035)\end{array}$ \\
\hline \multicolumn{4}{|c|}{ Canada Age 5-15 Months } \\
\hline $\begin{array}{l}\text { Mother: didn't want } \\
\text { pregnancy }\end{array}$ & 0.039 & 0.032 & $\begin{array}{l}-0.004 \\
(0.007)\end{array}$ \\
\hline $\begin{array}{l}\text { Mother: pregnancy at } \\
\text { right time }\end{array}$ & 0.473 & 0.464 & $\begin{array}{c}0.003 \\
(0.021)\end{array}$ \\
\hline $\begin{array}{l}\text { Partner: didn't want } \\
\text { pregnancy }\end{array}$ & 0.039 & 0.041 & $\begin{array}{l}-0.002 \\
(0.007)\end{array}$ \\
\hline $\begin{array}{l}\text { Partner: pregnancy at } \\
\text { right time }\end{array}$ & N.A. & N.A. & N.A. \\
\hline \multicolumn{4}{|l|}{ US Age 3-5 } \\
\hline $\begin{array}{l}\text { Mother: didn't want } \\
\text { pregnancy }\end{array}$ & 0.081 & 0.118 & $\begin{array}{l}-0.029 \\
(0.020)\end{array}$ \\
\hline $\begin{array}{l}\text { Mother: pregnancy at } \\
\text { right time }\end{array}$ & 0.517 & 0.482 & $\begin{array}{c}0.018 \\
(0.032)\end{array}$ \\
\hline $\begin{array}{l}\text { Partner: didn't want } \\
\text { pregnancy }\end{array}$ & 0.081 & 0.142 & $\begin{array}{c}-0.063 * * * \\
(0.022)\end{array}$ \\
\hline $\begin{array}{l}\text { Partner: pregnancy at } \\
\text { right time }\end{array}$ & 0.629 & 0.510 & $\begin{array}{c}0.098 * * * \\
(0.034)\end{array}$ \\
\hline
\end{tabular}

Notes: Authors' calculations from NSFG and MES data. Reported in the first two columns are the unconditional means of each dependent variable for the samples of male and female children. The third column reports the estimated coefficient on the male binary indicator in a regression including the control variables described in the appendix. Robust standard errors in parentheses. One star indicates significance at the 10 percent level; two stars for 5 percent; three stars for 1 percent. 
Table 9: Mothers' Time Inputs Promoting Cognition, U.K. — Twins

\begin{tabular}{lccc}
\hline & Males & Females & Difference \\
\hline Age 3 & & & \\
\hline Reading (mother) & 5.000 & 5.059 & -0.059 \\
& & & $(0.108)$ \\
Teach Alphabet & 3.357 & 3.532 & -0.175 \\
& & & $(0.165)$ \\
Teach Counting & 5.427 & 5.635 & -0.209 \\
Teach Songs & 6.168 & 6.468 & $-0.280^{* *}$ \\
Paint (PMK) & 4.959 & 5.272 & $(0.125)$ \\
& & & -0.313 \\
How often goes to & 1.518 & 1.589 & $(0.200)$ \\
library & & & -0.071 \\
\hline
\end{tabular}

Notes: Authors' calculations from MCS data. Reported in the first two columns are the unconditional means of each dependent variable for the samples of male and female children. The third column reports the estimated coefficient on the male binary indicator in a regression including the control variables described in the appendix. Robust standard errors in parentheses. One star indicates significance at the 10 percent level; two stars for 5 percent; three stars for 1 percent. 
Table 10: Parent's Expectations for their Children, U.K. -First Born

\begin{tabular}{|c|c|c|c|}
\hline & Males & Females & $\begin{array}{l}\text { Conditional } \\
\text { Difference }\end{array}$ \\
\hline \multicolumn{4}{|l|}{ Age 9 months } \\
\hline $\begin{array}{l}\text { Babies should be } \\
\text { picked up when crying }\end{array}$ & 0.327 & 0.308 & $\begin{array}{c}0.005 \\
(0.012)\end{array}$ \\
\hline $\begin{array}{l}\text { Babies need to be } \\
\text { stimulated }\end{array}$ & 0.959 & 0.950 & $\begin{array}{c}0.008 \\
(0.005)\end{array}$ \\
\hline $\begin{array}{l}\text { Talking to babies is } \\
\text { important }\end{array}$ & 0.995 & 0.993 & $\begin{array}{c}0.003 \\
(0.002)\end{array}$ \\
\hline $\begin{array}{l}\text { Cuddling a baby is } \\
\text { important }\end{array}$ & 0.991 & 0.988 & $\begin{array}{c}0.004 \\
(0.003)\end{array}$ \\
\hline \multicolumn{4}{|l|}{ Age 3} \\
\hline \multicolumn{4}{|c|}{$\underline{\text { Important to instill }}$} \\
\hline Obedience & 0.993 & 0.993 & $\begin{array}{l}-0.000 \\
(0.002)\end{array}$ \\
\hline Art of negotiation & 0.970 & 0.978 & $\begin{array}{l}-0.010^{*} \\
(0.005)\end{array}$ \\
\hline Respect for elders & 0.997 & 0.997 & $\begin{array}{l}-0.001 \\
(0.002)\end{array}$ \\
\hline Doing well at school & 0.992 & 0.994 & $\begin{array}{l}-0.003 \\
(0.002)\end{array}$ \\
\hline Religious values & 0.523 & 0.572 & $\begin{array}{c}-0.031 * * \\
(0.015)\end{array}$ \\
\hline Independence & 0.995 & 0.997 & $\begin{array}{l}-0.001 \\
(0.002)\end{array}$ \\
\hline \multicolumn{4}{|c|}{ Most important quality is } \\
\hline Well-liked & 0.042 & 0.033 & $\begin{array}{c}0.006 \\
(0.005)\end{array}$ \\
\hline Think independently & 0.507 & 0.523 & $\begin{array}{l}-0.013 \\
(0.015)\end{array}$ \\
\hline Work hard & 0.145 & 0.120 & $\begin{array}{c}0.023 * * \\
(0.010)\end{array}$ \\
\hline Help Others & 0.180 & 0.182 & $\begin{array}{c}0.006 \\
(0.012)\end{array}$ \\
\hline Obey Parents & 0.106 & 0.112 & $\begin{array}{l}-0.013 \\
(0.010)\end{array}$ \\
\hline Learn religious values & 0.019 & 0.029 & $\begin{array}{c}-0.009 * * \\
(0.004)\end{array}$ \\
\hline
\end{tabular}

Notes: Authors' calculations from MCS data. Reported in the first two columns are the unconditional means of each dependent variable for the samples of male and female children. The third column reports the estimated coefficient on the male binary indicator in a regression including the control variables described in the appendix. Robust standard errors in parentheses. One star indicates significance at the 10 percent level; two stars for 5 percent; three stars for 1 percent. 
Table 11: Reading Frequency in samples split by Mothers' Characteristics—First Born

\begin{tabular}{lccc}
\hline & US Age 2 years & $\begin{array}{c}\text { Canada Age 3-4 } \\
\text { Years }\end{array}$ & UK Age 3 years \\
\hline Mothers' Education & \multicolumn{3}{c}{} \\
\hline Mother HSG or less & -0.084 & -0.056 & $-0.122^{* * *}$ \\
Mother more than & $(0.057)$ & $(0.091)$ & $(0.043)$ \\
HSG & $-0.127 * * *$ & $-0.187 * * *$ & $-0.062^{* *}$ \\
Mothers' Employment & $(0.041)$ & $(0.048)$ & $(0.029)$ \\
\hline Mother works FT & -0.089 & & -0.041 \\
& $(0.057)$ & $-0.197 * * *$ & $(0.072)$ \\
Mother works PT & -0.086 & $(0.063)$ & $-0.099^{* * *}$ \\
& $(0.070)$ & $-0.157 * *$ & $(0.038)$ \\
Mother doesn't work & $-0.118^{* *}$ & $(0.070)$ & $-0.092^{*}$ \\
& $(0.055)$ & -0.035 & $(0.051)$ \\
\hline Mothers' Marital Status & & $(0.077)$ & -0.046 \\
\hline Mother Married & -0.065 & & $(0.031)$ \\
& $(0.040)$ & $-0.081^{*}$ & $(0.050)$ \\
Mother Cohabitating & $-0.265^{* * *}$ & $-0.285^{* *}$ & $(0.076)$ \\
& $(0.098)$ & $(0.112)$ & -0.066 \\
Mother Single & $-0.160^{* *}$ & -0.031 & $(0.076)$ \\
\hline
\end{tabular}

Notes: Authors' calculations from ECLS-B data for United States, NLSCY for Canada, and MCS for United Kingdom. The rows in this table define different samples on which the regression is run. The dependent variable is indicated for each country. Each entry in the table reports the estimated coefficient on the male binary indicator in a regression including the control variables described in the appendix. Robust standard errors in parentheses. One star indicates significance at the 10 percent level; two stars for 5 percent; three stars for 1 percent. 
Table 12: The Relationship between Cognitive Inputs and Developmental Outcomes

\begin{tabular}{|c|c|c|}
\hline & $\begin{array}{l}\text { Conditional } \\
\text { Difference }\end{array}$ & $\begin{array}{c}\text { Conditional on } \\
\text { Cognitive Inputs } \\
\text { Difference }\end{array}$ \\
\hline \multicolumn{3}{|l|}{ Panel A: United States } \\
\hline \multicolumn{3}{|l|}{ Reading Score at 4 years } \\
\hline Inputs measured at 9 months & $\begin{array}{c}-1.853 * * * \\
(0.454)\end{array}$ & $\begin{array}{c}-1.769 * * * \\
(0.449)\end{array}$ \\
\hline Inputs measured at 2 years & $\begin{array}{c}-1.850^{* * * *} \\
(0.454)\end{array}$ & $\begin{array}{c}-1.431 * * * \\
(0.451\end{array}$ \\
\hline \multicolumn{3}{|l|}{ Math Score at 4 years } \\
\hline Inputs measured at 9 months & $\begin{array}{c}-1.228 * * * \\
(0.390)\end{array}$ & $\begin{array}{c}-1.162 * * \\
(0.388)\end{array}$ \\
\hline Inputs measured at 2 years & $\begin{array}{c}-1.225^{* * *} * \\
(0.390)\end{array}$ & $\begin{array}{c}-0.913^{* *} \\
(0.389)\end{array}$ \\
\hline \multicolumn{3}{|l|}{ Panel B: Canada } \\
\hline \multicolumn{3}{|l|}{ PPVT At Ages 4-5 } \\
\hline Inputs measured in first interview & $\begin{array}{c}-2.436 * * * \\
(0.739)\end{array}$ & $\begin{array}{c}-2.327 * * * \\
(0.712)\end{array}$ \\
\hline Inputs measured in previous wave & $\begin{array}{c}-2.419 * * \\
(1.012) \\
\end{array}$ & $\begin{array}{c}-1.560 * \\
(0.908)\end{array}$ \\
\hline \multicolumn{3}{|l|}{ KYN At Ages 4-5 } \\
\hline Inputs measured in first interview & $\begin{array}{c}-0.066 * * * \\
(0.025)\end{array}$ & $\begin{array}{c}-0.063 * * * \\
(0.024)\end{array}$ \\
\hline Inputs measured in previous wave & $\begin{array}{l}-0.060^{*} \\
(0.037)\end{array}$ & $\begin{array}{l}-0.036 \\
(0.034)\end{array}$ \\
\hline \multicolumn{3}{|l|}{ Panel C: United Kingdom } \\
\hline \multicolumn{3}{|l|}{ Picture Similarity Score } \\
\hline Inputs measured at 3 years & $\begin{array}{c}-1.692 * * * \\
(0.338)\end{array}$ & $\begin{array}{c}-1.417 * * * \\
(0.371)\end{array}$ \\
\hline \multicolumn{3}{|l|}{ Naming Vocabulary Score } \\
\hline Inputs measured at 3 years & $\begin{array}{c}-0.608 \\
(0.416)\end{array}$ & $\begin{array}{l}-0.157 \\
(0.453)\end{array}$ \\
\hline \multicolumn{3}{|l|}{ Pattern Construction Score } \\
\hline Inputs measured at 3 years & $\begin{array}{c}-2.777 * * * \\
(0.533)\end{array}$ & $\begin{array}{c}-2.133 * * * \\
(0.562)\end{array}$ \\
\hline
\end{tabular}

Notes: Authors' calculations from ECLS-B data for United States, NLSCY for Canada, and MCS for United Kingdom. Reported is the coefficient on the male binary indicator in a regression including the control variables described in the appendix. The last column repeats the regression but includes the cognitive inputs reported in tables 4, 5, and 6 as control variables. Robust standard errors in parentheses. One star indicates significance at the 10 percent level; two stars for 5 percent; three stars for 1 percent. 